\title{
Electrochemical behaviour and electronic absorption of the metal $\beta$-diketonates complexes
}

\author{
Mohammed A. Al-Anber \\ Department of Chemical Science, Faculty of Science, Mu'tah University, 61710 Al-Karak, P.O. Box 7, Jordan \\ Department of Environmental Health, Faculty of Public Health and Health Informatics, Hail University, Hail, Saudi Arabia
}

Email address:

masachem@yahoo.com (M. A. Al-Anber)

To cite this article:

Mohammed A. Al-Anber. Electrochemical Behaviour and Electronic Absorption of the Metal $\beta$ - Diketonates Complexes. American Journal of Physical Chemistry Vol. 2, No. 1, 2013, pp. 1-7. doi: 10.11648/j.ajpc.20130201.11

\begin{abstract}
The electrochemical properties of $\beta$-diketonate complexes, such as [Co(tta)2(H2O)2], [Ni(tta)2(H2O)2], [Cu(tta)2] and [ $\mathrm{Zn}(\mathrm{tta}) 2(\mathrm{H} 2 \mathrm{O}) 2]$ (tta $=$ deprotonated of 1-thenoyl-4,4,4-trifluoroacetone) have been studied using cyclic voltammetry (CV). Their redox behaviors including oxidation and/ or reduction process for both central atom and tta ligand have been discussed. The cyclic voltammogrammes display one irreversible oxidation peak in a positive potential region, where it appears in the area between +1.30 and $+1.95 \mathrm{~V}$ based on the type of complex. In addition, two reduction peaks are appeared in the negative region potentials, at the region between -1.06 to $-2.16 \mathrm{~V}$. The irreversible oxidation potential peak of thienyl ring has shifted to the lower positive potential, while the reversibly redox potential peak of the fluorinated$\beta$-diketone moiety shifts to the higher negative potential compared with non-coordinated H-tta ligand. The spectral properties, energy levels, and energy gap for the respective complexes have been verified with UV-Vis spectrophotometer.
\end{abstract}

Keywords: Cyclic Voltammetry, $\beta$-Diketones, Electronic Spectra, 1-Thenoyl-4,4,4-Trifluoroacetone, Metal, Complex

\section{Introduction}

In the domain of material chemistry, metal $\beta$-diketonate complexes have attracted considerable interest because not only in the development of coordination chemistry and supramolecular chemistry, but also their potential applications in electro-materials [1-4]. The direct reaction between the metal ion and $\beta$-diketonate molecules can spontaneously produce the neutral homoleptic and heteroleptic metal $\beta$-diketonates complexes. In this context, new number of metal complexes including $\beta$-diketonates, such as (acac), hexaflouroacetyl-acetonate $(=$ hfac) [5], 1-(2thienyl)-4,4,4-triflouro-1,3-butanedione (= tta) [6], 1-(2furyl)-4,4,4-trifluoro-1,3-butanedione (= tfb) [7] and 3benzoyl-1.1.1-trifluoro-acetone (= tba) [8] have been extensively reported. For example, complexes $\left[\mathrm{Co}(\mathrm{tta})_{2}\left(\mathrm{H}_{2} \mathrm{O}\right)_{2}\right], \quad\left[\mathrm{Ni}(\mathrm{tta})_{2}\left(\mathrm{H}_{2} \mathrm{O}\right)_{2}\right], \quad\left[\mathrm{Cu}(\mathrm{tta})_{2}\right] \quad$ and $\left[\mathrm{Zn}(\mathrm{tta})_{2}\left(\mathrm{H}_{2} \mathrm{O}\right)_{2}\right](\mathrm{tta}=$ deprotonated of 1-thenoyl-4,4,4trifluoroacetone (H-tta)) were prepared by reacting of $\mathrm{H}$-tta with $\mathrm{M}(\mathrm{OAc})_{2} \cdot \mathrm{nH}_{2} \mathrm{O}\left(\mathrm{M}=\mathrm{Co}, \mathrm{Ni}, \mathrm{Cu}, \mathrm{Zn} ; \mathrm{OAc}=\mathrm{O}_{2} \mathrm{CMe}\right)$ $[8,9]$. Furthermore, a similar complexes including different metal centers, such as $\left[\mathrm{UO}_{2}(\mathrm{tfb})_{2}\right]_{n} . \mathrm{OHCH}_{3}(\mathrm{tfb}=$ deprotonated of 1-(2-furyl)-4,4,4-trifluoro-1,3-butanedione) and
$\left[\mathrm{Cu}(\mathrm{tba})_{2}\right](\mathrm{tba}=$ deprotonated of 3-benzoyl-1.1.1-trifluoroacetone) $[8,7]$, were prepared and structurally characterized.

Metal $\beta$-diketonates complexes possess properties that directly affected by the $\beta$-diketonates type surrounded around metal center. In particular, the chelated $\beta$-diketonates ligand and the molecular design can influence the redox properties of complexes. The redox properties can give insight into how the $\beta$-diketonates can stabilize the reduced or/ and oxidized form for the metal center in the complexes. Furthermore, it can provide us with useful information about the possibility of the use such complexes in the bioinorganic, electro- and catalytic systems. For these mentioned reasons, we find a lot of interested in studying the redox properties of these complexes.

Cyclic Voltammetry (CV) is perhaps the most effective and versatile electro-analytical technique available to study the mechanisms of a redox system of complexes. It enables the electrode potential to be rapidly scanned in search of redox couples [10]. The important parameters of cyclic voltammetry are the magnitude of the peak currents, $i_{\mathrm{pa}}$ and $i_{\mathrm{pc}}$, and the potentials at which peaks occur, $E_{\mathrm{pc}}$ and $E_{\mathrm{pa}}$. Reversible peaks have a distinct absolute potential difference between the reduction peak $\left(E_{\mathrm{pc}}\right)$ and oxidation peak 
$\left(E_{\mathrm{pa}}\right)$. In an ideal system $\left|E_{\mathrm{pc}}-E_{\mathrm{pa}}\right|$ would be $59 \mathrm{mV}$ for a 1 electron process and $30 \mathrm{mV}$ for a 2 electron process [11]. In addition, the ratio of the currents passed at reduction $\left(i_{\mathrm{pc}}\right)$ and end oxidation $\left(i_{\mathrm{pa}}\right)$ is near unity $\left(i_{\mathrm{pa}} / i_{p c}=1\right)$ for a reversible peak. When such reversible peaks are observed thermodynamic information in the form of half cell potential $E_{1 / 2}^{0}$ can be determined. When peaks are semi-reversible such as when $\left(i_{\mathrm{pa}} / i_{p c}\right.$ is less than or greater than 1 , it can be possible to determine even more information especially kinetic processes like following chemical reaction. When peaks are non-reversible it is impossible to determine what their thermodynamic $E_{1 / 2}$ is with cyclic voltammetry.

Our new interest has focused in supramolecular of MOFs that have been formed by a self assembly of $\beta$-diketonate ligands with divalent metal ions. To keep these materials in touch with applications, the physical and chemical properties must be studied. Up to our knowledge, nobody uses the cyclic voltammetry to study the redox properties of these materials, knowing that these materials have been recently prepared and characterized [9]. Therefore, we have performed cyclicvoltammetry to show the influence of 1-(2-thienyl) -4, 4, 4-triflouro-1, 3butanedione ligand on the redox potential of divalent metal ions. In addition, the electronic transition spectra are measured to show the influence energy gaps.

\section{Experimental}

\subsection{General Remarks}

Complexes $\left[\mathrm{Co}(\mathrm{tta})_{2}\left(\mathrm{H}_{2} \mathrm{O}\right)_{2}\right],\left[\mathrm{Ni}(\mathrm{tta})_{2}\left(\mathrm{H}_{2} \mathrm{O}\right)_{2}\right],\left[\mathrm{Cu}(\mathrm{tta})_{2}\right]$ and $\left[\mathrm{Zn}(\mathrm{tta})_{2}\left(\mathrm{H}_{2} \mathrm{O}\right)_{2}\right](\mathrm{tta}=$ deprotonated of 1-thenoyl4,4,4-trifluoroacetone (H-tta)) were prepared by reacting of $\mathrm{H}$-tta with $\mathrm{M}(\mathrm{OAc})_{2} \cdot \mathrm{nH}_{2} \mathrm{O}(\mathrm{M}=\mathrm{Co}, \mathrm{Ni}, \mathrm{Cu}, \mathrm{Zn} ; \mathrm{OAc}=$ $\mathrm{O}_{2} \mathrm{CMe}$ ) in a 2:1 molar ratio in warm ethanol (Scheme 1) $[8,9]$. After appropriate work up, all complexes could be isolated as brown, dark green, light-green and collarless solids, respectively. Others are analytical grade chemicals were purchased from commercial providers and were used as received.

-Please insert Scheme 1 herein-

\subsection{Physical Measurements}

Cyclicvoltammetry (CV) was performed with a onecompartment glass cell with a platinum disc (and for solid film deposition using a platinum plate) $\left(1 \mathrm{~mm}^{2}\right.$ apparent surface area, $99 \%$, Schiefer, Hamburg) or a glassy carbon disc (HTW, Thierhaupten) embedded into a PTFE cylinder as working electrode. A platinum wire counter electrode and a silver reference electrode $\left(\mathrm{Ag} / \mathrm{Ag}^{+}, 0.01 \mathrm{M} \mathrm{AgNO}_{3}\right.$ in a solution of $0.1 \mathrm{M}$ tetra-n-butyl ammonium hexafluorophosphate, TBFP (Fluka, dried in an oil pump vacuum at $120{ }^{\circ} \mathrm{C}$ ) in acetonitrile) were used. For ease of comparison, all electrode potentials were converted using the ferrocene/ferrocenium redox couple as a reference point $\left(E_{\mathrm{FeC}}=\right.$ $0 \mathrm{mV}$ ) [12]. All CVs were run at a scan rate of $\mathrm{d} E / \mathrm{d} t=200$
$\mathrm{mV} \mathrm{s}^{-1}$ using an electrolyte solution of $0.1 \mathrm{M}$ of tetra-nbutyl ammonium hexafluorophosphate in acetonitrile with a concentration of the compounds of $5 \mathrm{mM}$. CVs were recorded using a Volta-lab 3.1 potentiostat (Radiometer) equipped with a digital electrochemical analyzer DEA 101 and an electrochemical interface IMT 102. All experiments were run at room temperature $\left(25^{\circ} \mathrm{C}\right)$ under Argon purified with a $\mathrm{CuO}$ catalyst for dioxygen removal. The electronic spectra of all molecules are recorded in acetonitrile solution. The electronic spectra have been measured for the same solution under inert argon gas using a Perkin-Elmer Lambda $650 \mathrm{UV}$-vis spectrophotometer, working in the wavelength range 190-900 $\mathrm{nm}$.

\section{Result and Discussion}

\subsection{Electrochemical Behaviour}

The electrochemical behavior of $\left[\mathrm{Ni}(\mathrm{tta})_{2}\left(\mathrm{H}_{2} \mathrm{O}\right)_{2}\right]$, $\left[\mathrm{Co}(\mathrm{tta})_{2}\left(\mathrm{H}_{2} \mathrm{O}\right)_{2}\right],\left[\mathrm{Cu}(\mathrm{tta})_{2}\right]$, and $\left[\mathrm{Zn}(\mathrm{tta})_{2}\left(\mathrm{H}_{2} \mathrm{O}\right)_{2}\right]$ are carried out using cyclic voltammetry in acetonitrile solution. The scan rate was a $200 \mathrm{mV} / \mathrm{s}$. The electrochemical data of the respective complexes are listed in the Table 1. The cyclic voltammogram of the GC electrode in $0.1 \mathrm{M}$ of tetra-nbutyl ammonium hexafluorophosphate in acetonitrile solution in the absence of any complex shows no electron exchange occurred as shown in Figure 1. With the addition of the 1-thenoyl-4,4,4-trifluoroacetone ( = tta) ligands one irreversible anodic peak at $E_{p a}=+1.88 \mathrm{~V}$ is appeared (see Figure 2). This potential peak relates to the oxidation of thienyl unit [13-14]. When the scanning was going toward the negative potential, the cyclic voltammogram exhibited one cathodic reversible redox peak at $E_{1 / 2}=-1.10 \mathrm{~V}(\Delta E=$ $570 \mathrm{mV}$ ) vs. $\mathrm{Cp}_{2} \mathrm{Fe} / \mathrm{Cp}_{2} \mathrm{Fe}$ as shown in the Figure 2. This redox peak corresponds to the reduction peak for the fluorinated $\beta$-diketone fragment [14].

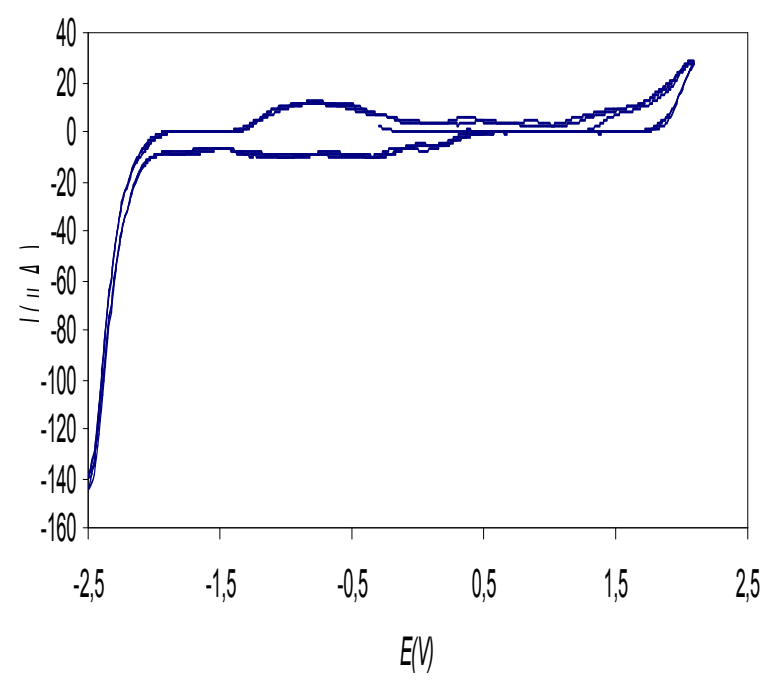

Fig. 1. Cyclic voltammogram of acetonitrile solvent $\left(c=2.0 \times 10^{-3} \mathrm{M}\right)$ in the presence of $\left[n-B u_{4} N\right]\left[P F_{6}\right](c=0.1 \mathrm{M})$ at $25^{\circ} \mathrm{C}$ under argon at a scan rate of $200 \mathrm{mV} \mathrm{s}^{-1}$; potentials are referenced to $\mathrm{FcH} / \mathrm{FcH}^{+}$as internal standard. 


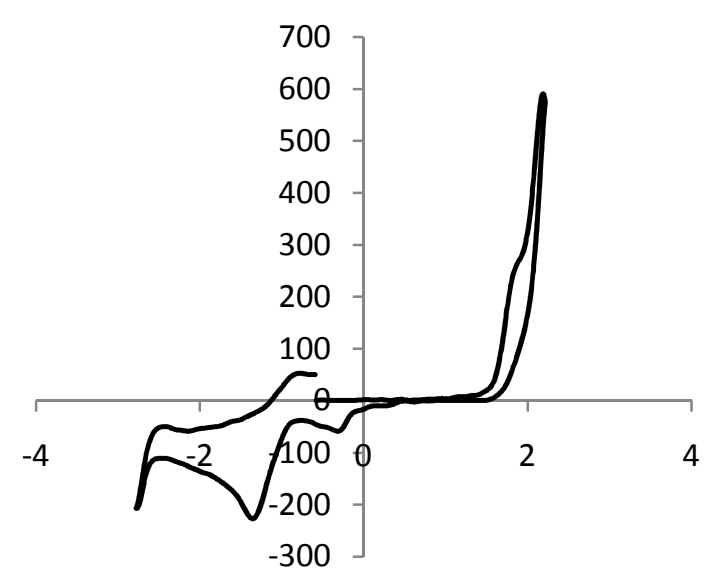

Fig. 2. Cyclic voltammogram of H-tta ligand in $6 \mathrm{ml}$ acetonitrile solution $(c=2.0 \times 10-3 M)$ in the presence of $[n-B u 4 N][P F 6](c=0.1 \mathrm{M})$ at $25^{\circ} \mathrm{C}$ under argon at a scan rate of $200 \mathrm{mV} \mathrm{s}-1$; potentials are referenced to $\mathrm{FCH} / \mathrm{FcH}+$ as internal standard $(\mathrm{E} 1 / 2=0.00 \mathrm{~V}, \mathrm{CH} 3 \mathrm{CN})$.

Table 1. Cyclic Voltammetric data for H-tta and their metal $\beta$-diketonates complexes.

\begin{tabular}{|c|c|c|c|c|c|c|}
\hline & Negati & e pote & ntial & & & $\begin{array}{l}\text { Positive } \\
\text { potential } \\
\text { (thiophene } \\
\text { ring) }\end{array}$ \\
\hline Complex & $\begin{array}{l}E_{\text {red }} / \\
\mathbf{V}\end{array}$ & $\begin{array}{l}E_{\text {oxid }} / \\
\mathbf{V}\end{array}$ & $\begin{array}{l}E_{1 / 2} / \\
V\end{array}$ & $\begin{array}{c}\Delta E / \\
\mathbf{m V}\end{array}$ & $\begin{array}{l}E_{\text {oxid }} / \\
\text { V }\end{array}$ & $\begin{array}{l}E_{\text {oxid }} / \\
\text { V }\end{array}$ \\
\hline H-tta & 1.38 & 0.81 & 1.10 & 570 & & +1.88 \\
\hline$\left[\mathrm{Co}(\mathrm{tta})_{2}\left(\mathrm{H}_{2} \mathrm{O}\right)_{2}\right]$ & $\begin{array}{l}1.90 \\
2.16\end{array}$ & 1.92 & 2.04 & 240 & & +1.31 \\
\hline$\left[\mathrm{Ni}(\mathrm{tta})_{2}\left(\mathrm{H}_{2} \mathrm{O}\right)_{2}\right]$ & $\begin{array}{l}2.11 \\
2.31\end{array}$ & 2.09 & 2.20 & 220 & & $\begin{array}{l}+1.40 \\
+1.64\end{array}$ \\
\hline$\left[\mathrm{Ni}(\mathrm{OAc})_{2} .2 \mathrm{H}_{2} \mathrm{O}\right]$ & 1.80 & & & & & \\
\hline$\left[\mathrm{Zn}(\mathrm{tta})_{2}\left(\mathrm{H}_{2} \mathrm{O}\right)_{2}\right]$ & $\begin{array}{l}1.70 \\
2.08\end{array}$ & 1.82 & 1.93 & 310 & & +1.53 (broad) \\
\hline$\left[\mathrm{Cu}(\mathrm{OAc})_{2} \cdot \mathrm{H}_{2} \mathrm{O}\right]$ & $\begin{array}{r}\{0.97 \\
1.62\}\end{array}$ & $\{0.5\}$ & & & +1.16 & \\
\hline$\left[\mathrm{Cu}(\mathrm{tta})_{2}\right]$ & $\begin{array}{l}\tilde{\{} 1.06 \\
1.66\}\end{array}$ & $\{0.5\}$ & $\begin{array}{l}0.82 \\
1.12\end{array}$ & $\begin{array}{l}480 \\
1080\end{array}$ & 0.81 & $\begin{array}{l}+\quad 1.95 \\
0.73)\end{array}$ \\
\hline
\end{tabular}

The electrochemical data for the second and third cycle.

The $\left[\mathrm{Cu}(\mathrm{tta})_{2}\right]$ complex exhibits initially two reduction peaks in the negative region at $E_{p c}=-1.06$ and $-1.66 \mathrm{~V}$ with a large corresponding oxidation peak at $E_{p c}=-0.58$
$\mathrm{V}$ as shown in Figure 3 . The peak separation $(\Delta \mathrm{E})$ of this couple $\left[E_{1 / 2}=-0.82\right.$ and $\left.-1.12 \mathrm{~V}\right]$ is 480 and $1080 \mathrm{mV}$, respectively. Furthermore, it exhibits one irreversible oxidation peak in the positive region at $E_{p a}=+1.95 \mathrm{~V}$. In analogy to the reported electrochemical data of thiophene and oligothiphene [13-14] and previously reported copper complexes: i) the first reversible redox peak correspond to the reduction behavior of copper atom. ii) the second reduction process corresponds to the reduction of the fluorinated $\beta$-diketone fragment. iii) The irreversible anodic peak is related to the oxidation of theinyl ring. Copper complex exhibits two redox processes, each reduction is associated with a single-electron transfer process. The reduction peak corresponds to the first electron transfer of $\mathrm{Cu}(\mathrm{II}) \rightarrow \mathrm{Cu}(\mathrm{I})$ process, which is overlapped with the reduction peak of fluorinated $\beta$-diketone unit. The $E_{\mathrm{pc}}$ and $E_{\mathrm{pa}}$ values were observed in agreement with the reported results [15-17]. In compression, the reduction potentials of $\mathrm{Cu}$ (II) exhibits more negative potential value than $\mathrm{Cu}(\mathrm{OAc})_{2} \cdot \mathrm{H}_{2} \mathrm{O}\left[E_{p c}=-0.97 \mathrm{~V}\right.$ and $-1.62 \mathrm{~V}, \Delta E=0.45 \mathrm{~V}$ and $1.10 \mathrm{~V}, E_{1 / 2}=-0.75 \mathrm{~V}$ and $\left.-1.07 \mathrm{~V}\right]$ (see Figure 4). The most significant feature in the cyclic voltammogram of both $\left[\mathrm{Cu}(\mathrm{tta})_{2}\right]$ and $\mathrm{Cu}(\mathrm{OAc})_{2} \cdot \mathrm{H}_{2} \mathrm{O}$ is the ratio of each cathodic to an anodic peak height. It is slightly more than two. During continued scanning in the negative region up to $1.50 \mathrm{~V}$ only, the height of this ratio becomes one (see Figures 3 and 4). This indicates that the large anodic oxidation peak (at $E_{p a}=-0.58 \mathrm{~V}$ ) corresponds to the two oxidation processes. One of them relates to the anodic peak of fluorinated $\beta$-diketone unit. The reduction potential of $\AA$-diketonate is found less negative than non-coordinated $\mathrm{H}$-tta ligand. One explanation for the defaulting reduction of $\mathrm{Cu}(\mathrm{II})$ is an electron-withdrawing effect of fluoride atoms anchored in tta ligand. The reduction in electron density on the copper and distortion in geometry may influence facial conversion of $\mathrm{Cu}(\mathrm{II}) \rightarrow \mathrm{Cu}(\mathrm{I})$. The easier reduction of $\AA$-diketonate ligand suggests a LUMO level decrease in energy. Moreover, the cyclic voltammogram exhibits further irreversible anodic peak at $+0.81 \mathrm{~V}$, which is probably attributed to the $\mathrm{Cu}(\mathrm{II}) / \mathrm{Cu}(\mathrm{III})$ couple. This peak was reported in one of the previous studies [18], where it was identical with the value obtained from this study. It shifted to the less positive potential compared with $\mathrm{Cu}(\mathrm{OAc})_{2} \cdot \mathrm{H}_{2} \mathrm{O}$ (see Table 1 ). When the scanning is going further toward the positive potential, the cyclic voltammogram of $\left[\mathrm{Cu}(\mathrm{tta})_{2}\right]$ complex exhibit irreversible anodic peak at $+1.95 \mathrm{~V}$. In analogy to the reported electrochemical data of thiophene and oligothiphene [13-14], this oxidation potential is related to the thiophene moiety. This oxidation potential shift to the more positive potential compared to the non-coordinated $\mathrm{H}$-tta ligand $(+1.88 \mathrm{~V})$. This observed peak corresponds to a backward shoulder at $-0.07 \mathrm{~V}$. This shoulder was shown previously at $-0.10 \mathrm{~V}$ in the cyclic voltammogram of H-tta ligand as shown in Figure 3. It is appeared after the oxidation of thiophene rings. This may due to the changing in the thiophene ring through the elec- 
trochemical measurement.

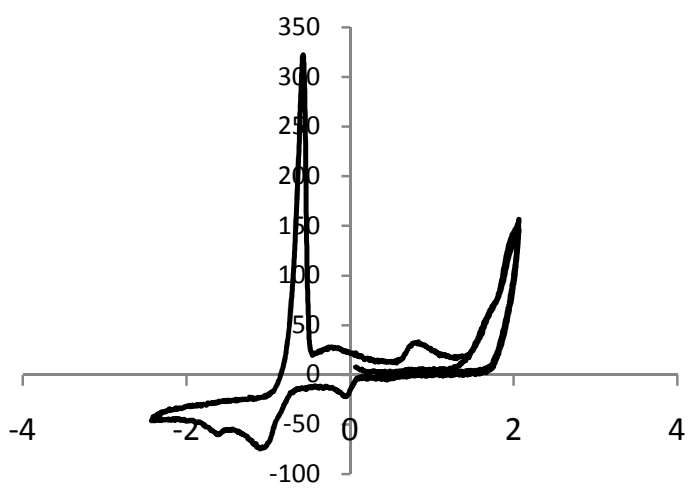

Fig. 3. Cyclic voltammogram of [Cu(tta)2] in $6 \mathrm{ml}$ acetonitrile solution $(c=2.0 \times 10-3 M)$ in the presence of $[n-B u 4 N][P F 6](c=0.1 \mathrm{M})$ at $25{ }^{\circ} \mathrm{C}$ under argon at a scan rate of $200 \mathrm{mV} \mathrm{s}-1$; potentials are referenced to $\mathrm{FcH} / \mathrm{FcH}+$ as internal standard $(\mathrm{E} 1 / 2=0.00 \mathrm{~V}, \mathrm{CH} 3 \mathrm{CN})$.

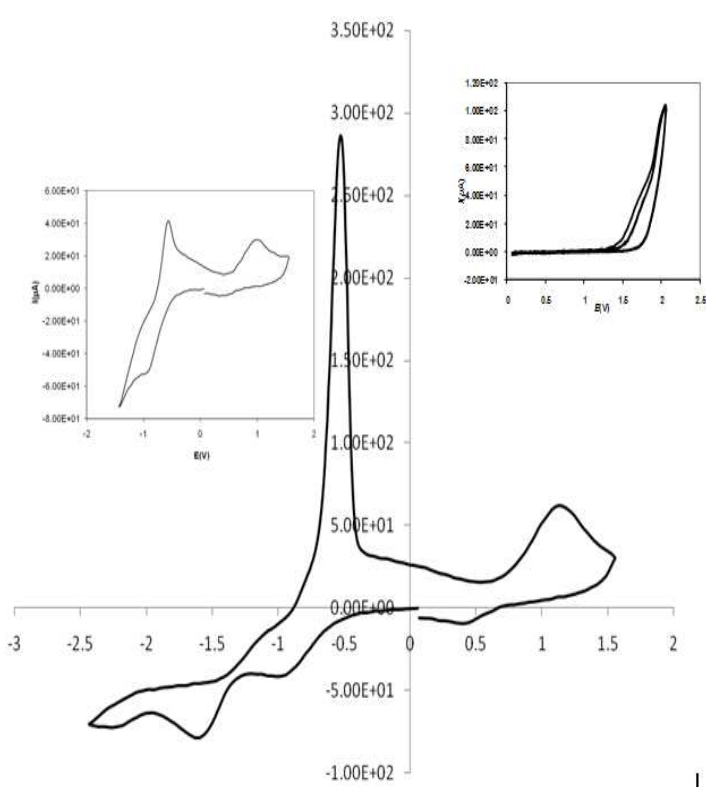

Fig. 4. Cyclic voltammogram of $\mathrm{Cu}(\mathrm{OAc})_{2} \cdot \mathrm{H}_{2} \mathrm{O}$ in $6 \mathrm{ml}$ acetonitrile solution $\left(c=2.0 \times 10^{-3} \mathrm{M}\right)$ in the presence of $\left[n-B u_{4} N\right]\left[P F_{6}\right](c=0.1 \mathrm{M})$ at $25^{\circ} \mathrm{C}$ under argon at a scan rate of $200 \mathrm{mV} \mathrm{s}^{-1}$; potentials are referenced to $\mathrm{FcH} / \mathrm{FcH}^{+}$as internal standard $\left(E_{1 / 2}=0.00 \mathrm{~V}, \mathrm{CH}_{3} \mathrm{CN}\right)$.

A cyclic voltammogram of $\left[\mathrm{Ni}(\mathrm{tta})_{2}\left(\mathrm{H}_{2} \mathrm{O}\right)_{2}\right]$ is presented in Figure 5, which displays an irreversible reduction peak at $E_{p c}=-2.11 \mathrm{~V}$ and one reversible reduction peak at $E_{p c}$ $=-2.31 \mathrm{~V}$. This reversible-mentioned peak associates with a backward oxidation peak at $E_{p a}=-2.09 \mathrm{~V}[\Delta E=0.22 \mathrm{~V}$ and $\left.1.10 \mathrm{~V}, E_{1 / 2}=-2.20 \mathrm{~V}\right]$. This redox peak corresponds to the reduction peak of the fluorinated $\beta$-diketone fragment. The cathodic irreversible peak corresponds to the reduction peak of the $\mathrm{Ni}(\mathrm{II}) \rightarrow \mathrm{Ni}(\mathrm{I})$. This cathodic irreversible peak shift to the more negative potential compared to $\mathrm{Ni}(\mathrm{OAc})_{2} \cdot 6 \mathrm{H}_{2} \mathrm{O}(-1.80 \mathrm{~V})$ (see Figure 6). As the scan is going to the more positive potential up to $+2.50 \mathrm{~V}$, two anodic irreversible peaks at +1.40 (as a major peak) and $+1.64 \mathrm{~V}$ (as a minor peak) are observed. These anodic potentials correspond to the oxidation of thienyl ring. In addi- tion, these major and minor oxidation potentials shifts to the lower potential compared to non-coordinated H-tta ligand. The main reason for such shift is due to the extending of the $\pi$-systems in complex through $\mathrm{O}-\mathrm{M}-\mathrm{O}$ unit.

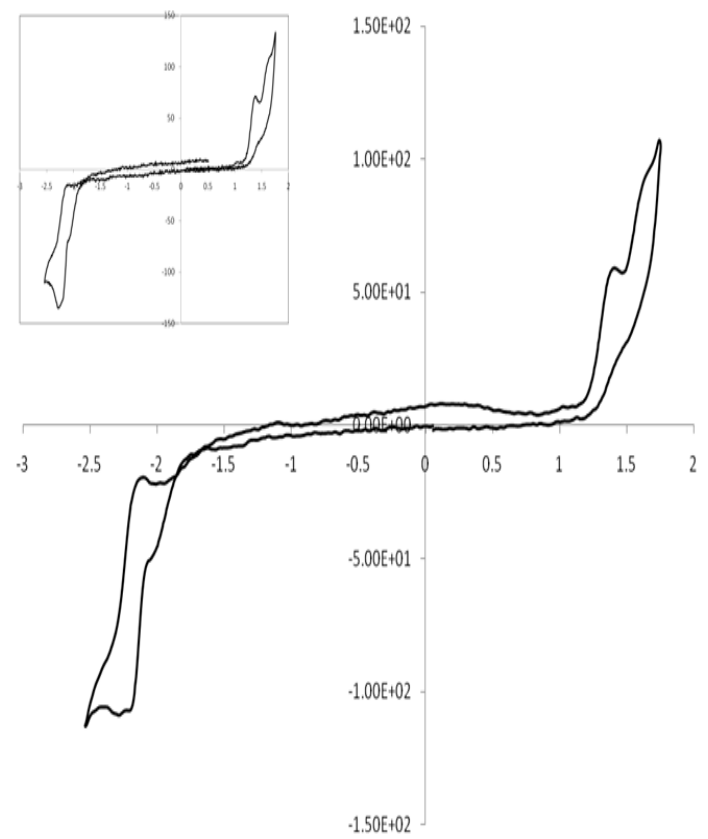

Fig. 5. Cyclic voltammogram of $\left[\mathrm{Ni}(\mathrm{tta})_{2}\left(\mathrm{H}_{2} \mathrm{O}\right)_{2}\right]$ in $6 \mathrm{ml}$ acetonitrile solution $\left(c=2.0 \times 10^{-3} \mathrm{M}\right)$ in the presence of $\left[n-B u_{4} N\right]\left[P F_{6}\right](c=0.1 \mathrm{M})$ at $25^{\circ} \mathrm{C}$ under argon at a scan rate of $200 \mathrm{mV} \mathrm{s}^{-1}$; potentials are referenced to $\mathrm{FcH} / \mathrm{FcH}^{+}$as internal standard $\left(E_{1 / 2}=0.00 \mathrm{~V}, \mathrm{CH}_{3} \mathrm{CN}\right)$.

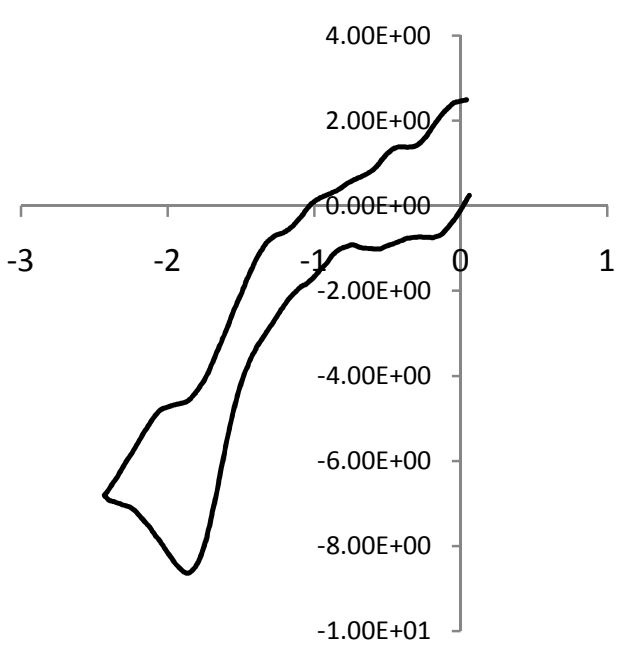

Fig. 6. Cyclic voltammogram of $\mathrm{Ni}(\mathrm{OAc})_{2} .4 \mathrm{H}_{2} \mathrm{O}$ in $6 \mathrm{ml}$ acetonitrile solution $\left(c=2.0 \times 10^{-3} \mathrm{M}\right)$ in the presence of $\left[n-B u_{4} N\right]\left[P F_{6}\right](c=0.1 \mathrm{M}) \mathrm{at}$ $25^{\circ} \mathrm{C}$ under argon at a scan rate of $200 \mathrm{mV} \mathrm{s}^{-1}$; potentials are referenced to $\mathrm{FcH} / \mathrm{FCH}^{+}$as internal standard $\left(\mathrm{E}_{1 / 2}=0.00 \mathrm{~V}, \mathrm{CH}_{3} \mathrm{CN}\right)$.

Figure 7 represents the cyclic voltammogram of $\left[\mathrm{Co}(\mathrm{tta})_{2}\left(\mathrm{H}_{2} \mathrm{O}\right)_{2}\right]$. The $\mathrm{CV}$ measurements shows that $\left[\mathrm{Co}(\mathrm{tta})_{2}\left(\mathrm{H}_{2} \mathrm{O}\right)_{2}\right]$ complex exhibits similar electrochemical behavior of the $\left[\mathrm{Ni}(\mathrm{tta})_{2}\left(\mathrm{H}_{2} \mathrm{O}\right)_{2}\right]$ complex. The main differences between the $\mathrm{CVs}$ of $\left[\mathrm{Co}(\mathrm{tta})_{2}\left(\mathrm{H}_{2} \mathrm{O}\right)_{2}\right]$ and 
$\left[\mathrm{Ni}(\mathrm{tta})_{2}\left(\mathrm{H}_{2} \mathrm{O}\right)_{2}\right]$ complexes are: i) the redox potential of the fluorinated $\beta$-diketone fragment $\left[E_{1 / 2}=-2.04 \mathrm{~V}\right]$ shifts to the lower potentials compared to $\mathrm{H}$-tta ligand and [Ni(tta) $\left.)_{2}\left(\mathrm{H}_{2} \mathrm{O}\right)_{2}\right]$ complex [19]. Here again, the reaction of $H$-tta ligand with nickel or cobalt is followed by a ca. 310 $\mathrm{mV}$ more negative shifts. The cathodic irreversible peak $\left(E_{p a}=-1.90 \mathrm{~V}\right)$, we suggest, regard to the reducing of $\mathrm{Co}(\mathrm{II}) \rightarrow \mathrm{Co}(\mathrm{I})$. ii) The $\mathrm{CV}$ of $\left[\mathrm{Ni}(\mathrm{tta})_{2}\left(\mathrm{H}_{2} \mathrm{O}\right)_{2}\right]$ complex display only one reversible mono-electronic redox process. This could be assigned to the reducing of $\mathrm{Ni}(\mathrm{II}) \rightarrow \mathrm{Ni}(\mathrm{I})$. The redox potential of nickel complex is $c a .160 \mathrm{mV}$ more negative than the redox potential of cobalt complex. This reflects a higher electron density at the cobalt center. iii) the oxidation potential of thiophene ring $\left(E_{\mathrm{pa}}=+1.31 \mathrm{~V}\right)$ was observed as one major irreversible peak. It shifted to the lower positive potential compared to $H$-tta ligand and $\left[\mathrm{Ni}(\mathrm{tta})_{2}\left(\mathrm{H}_{2} \mathrm{O}\right)_{2}\right]$ complex.

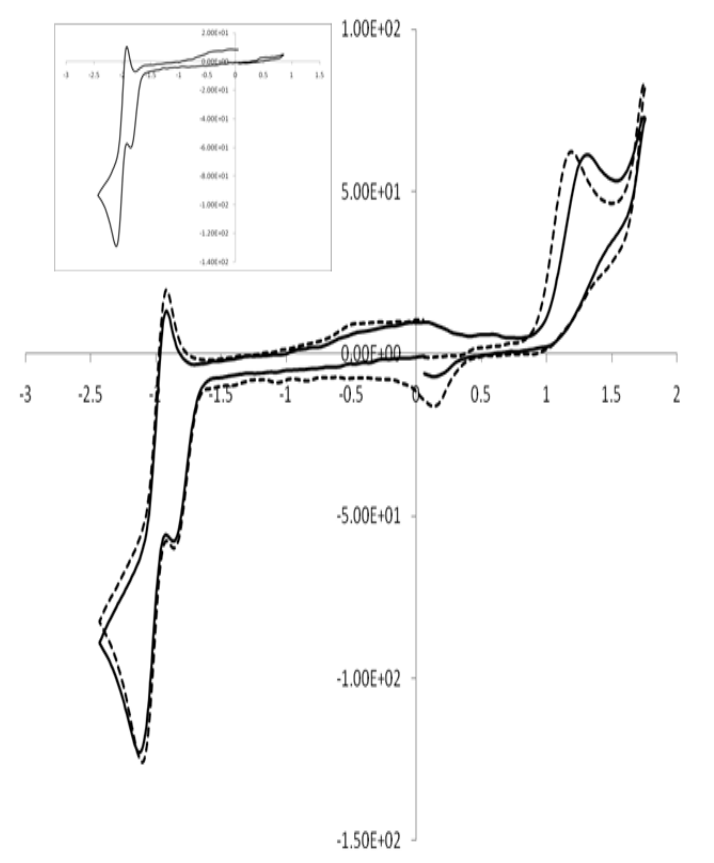

Fig. 7. Cyclic voltammogram of $\left[\mathrm{Co}(\mathrm{tta})_{2}\left(\mathrm{H}_{2} \mathrm{O}\right)_{2}\right]$ in $6 \mathrm{ml}$ acetonitrile solution $\left(c=2.0 \times 10^{-3} \mathrm{M}\right)$ in the presence of $\left[n-B u_{4} N\right]\left[\mathrm{PF}_{6}\right](c=0.1 \mathrm{M})$ at $25^{\circ} \mathrm{C}$ under argon at a scan rate of $200 \mathrm{mV} \mathrm{s}^{-1}$; potentials are referenced to $\mathrm{FcH} / \mathrm{FcH}^{+}$as internal standard $\left(E_{1 / 2}=0.00 \mathrm{~V}, \mathrm{CH}_{3} \mathrm{CN}\right)$.

Figure 8 shows the cyclic voltammogram of $\left[\mathrm{Zn}(\operatorname{tta})_{2}\left(\mathrm{H}_{2} \mathrm{O}\right)_{2}\right]$. The voltammogram exhibits initially two cathodic peaks. It has been observed that the first peak $\left(E_{p a}\right.$ $=-1.90 \mathrm{~V})$ is irreversible. This could be related to the reducing of $\mathrm{Zn}(\mathrm{II}) \rightarrow \mathrm{Zn}(\mathrm{I})$. The second cathodic peaks is reversible redox $\left[E_{p a}=-2.08 \mathrm{~V}, \Delta E=260 \mathrm{mV}\right.$ and $E_{1 / 2}=-$ $1.93 \mathrm{~V}]$. It can be related for reducing of the fluorinated $\beta$ diketone unit. In the positive region up to $+2.50 \mathrm{~V}$, one irreversible oxidation potential peak $\left(E_{p a}=+1.53 \mathrm{~V}\right)$ was observed for the thiophene ${ }^{+} /$thiophene redox couple. In compression with the electrochemical data for H-tta [15-16] and their complexes (in this study), some differences are: i) the redox couple of the fluorinated $\beta$-diketone unit $\left(\mathrm{E}_{\mathrm{red}}=-\right.$ $1.93 \mathrm{~V}$ ) shifts to the higher negative potential compared to un-coordinated $\mathrm{H}$-tta $\left(E_{1 / 2}=-1.10 \mathrm{~V}\right)$. ii) it shifted to the lower negative potential compared to the $\left[\mathrm{Co}(\mathrm{tta})_{2}\left(\mathrm{H}_{2} \mathrm{O}\right)_{2}\right]$ and $\left[\mathrm{Ni}(\mathrm{tta})_{2}\left(\mathrm{H}_{2} \mathrm{O}\right)_{2}\right]$ complexes, but it was found higher than the $\mathrm{Cu}(\mathrm{tta})_{2}$ complex. iii) The oxidation potential of thienyl ring $\left(E_{p a}=+1.53 \mathrm{~V}\right)$ shifts to the lower positive potential compared to $H$-tta $\left(E_{p a}=+1.88 \mathrm{~V}\right)$ ligand. The direct reaction of a $\mathrm{H}$-tta ligand with zinc(II) followed one irreversible mono-electronic reduction process at a much more negative potentials $\left(E_{p c}=-1.70 \mathrm{~V}\right)$ that assigned to $\mathrm{Zn}(\mathrm{II}) \rightarrow \mathrm{Zn}(\mathrm{I})$ [20]. This redox value is less than the nickel and cobalt complex by 410 and $360 \mathrm{mV}$, respectively. This reflects a higher electron density at the $\mathrm{Zn}$ (II) atom compared to $\mathrm{Co}(\mathrm{II})$ and $\mathrm{Ni}(\mathrm{II})$ atoms.

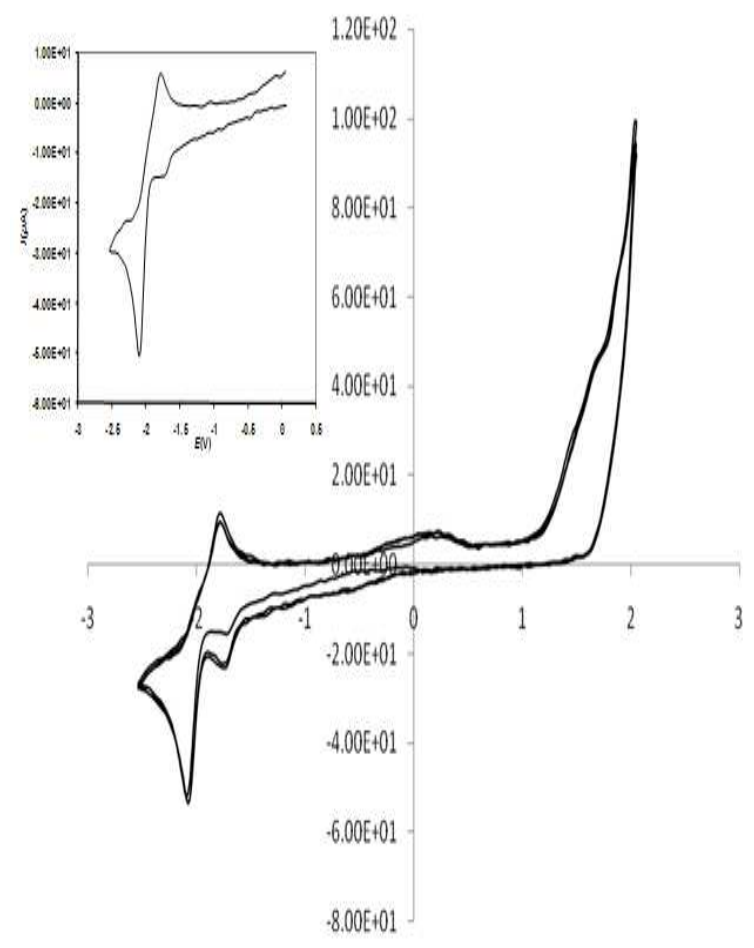

Fig. 8. Cyclic voltammogram of $\left[\mathrm{Zn}(\mathrm{tta})_{2}\left(\mathrm{H}_{2} \mathrm{O}\right)_{2}\right]$ in $6 \mathrm{ml}$ acetonitrile solution $\left(c=2.0 \times 10^{-3} \mathrm{M}\right)$ in the presence of $\left[n-B u_{4} N\right]\left[P F_{6}\right](c=0.1 \mathrm{M})$ at $25^{\circ} \mathrm{C}$ under argon at a scan rate of $200 \mathrm{mV} \mathrm{s}^{-1}$; potentials are referenced to $\mathrm{FcH} / \mathrm{FcH}^{+}$as internal standard $\left(E_{1 / 2}=0.00 \mathrm{~V}, \mathrm{CH}_{3} \mathrm{CN}\right)$.

\subsection{Electronic Behavior}

Electrochemical potential and the energy band gap are among the most important physical properties to be taken into account in order to envision applications of the material. Therefore, the electronic transition band and transition energies are calculated using UV-Vis spectrophotometer. The electronic spectral measurements were used for assigning the stereo-chemistries of metal complexes based on the positions and number of $d-d$ transition peaks. The electronic absorption spectra of metal(II) complexes were recorded in $10^{-3} \mathrm{M}$ in acetonitrile in the range $200-1100 \mathrm{~nm}$ at room temperature. The results of the solution spectra are pre- 
sented in Figure 9 and Table 2.

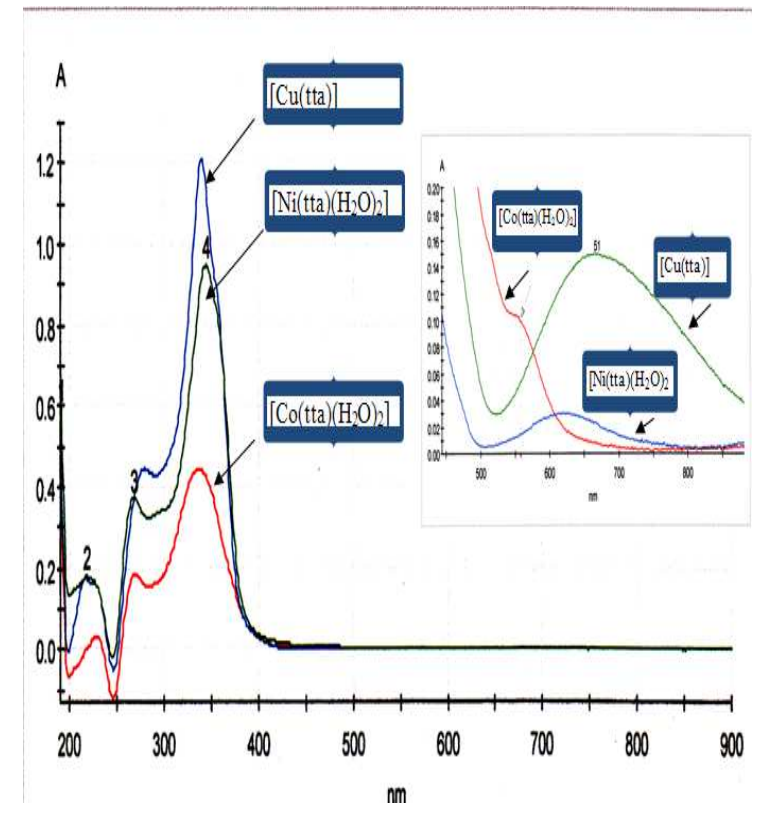

Fig 9. Electronic Absorption for [Co(tta $\left.)_{2}\left(\mathrm{H}_{2} \mathrm{O}\right)_{2}\right],\left[\mathrm{Ni}(\mathrm{tta})_{2}\left(\mathrm{H}_{2} \mathrm{O}\right)_{2}\right]$ and $\left[\mathrm{Cu}(\mathrm{tta})_{2}\right]\left(\mathrm{tta}=\right.$ deprotonated of 1-thenoyl-4,4,4-trifluoroacetone) in $10^{-3}$ $M$ acetonitril solution.

Table 2. UV-Vis spectroscopic data for H-tta and their metal $\beta$-diketonates complexes

\begin{tabular}{|c|c|c|c|}
\hline Complex & $\lambda_{\max }(\mathrm{nm})$ & Abs & $\varepsilon_{\max }\left(\operatorname{lmol}^{-1} \mathrm{~cm}^{-1}\right)$ \\
\hline H-tta & $\begin{array}{l}273 \\
323\end{array}$ & $\begin{array}{l}0.610 \\
1,090\end{array}$ & 54500 \\
\hline $\begin{array}{l}{\left[\mathrm{Co}(\mathrm{tta})_{2}\left(\mathrm{H}_{2} \mathrm{O}\right)_{2}\right]} \\
d-d \\
{\left[\mathrm{Co}(\mathrm{OAc})_{2} \cdot 2 \mathrm{H}_{2} \mathrm{O}\right]} \\
d-d\end{array}$ & $\begin{array}{l}229 \\
269 \\
337 \\
563 \\
193 \\
390\end{array}$ & $\begin{array}{l}0,033 \\
0,185 \\
0,444\end{array}$ & $\begin{array}{l}1650 \\
9250 \\
22200\end{array}$ \\
\hline $\begin{array}{l}{\left[\mathrm{Ni}(\mathrm{tta})_{2}\left(\mathrm{H}_{2} \mathrm{O}\right)_{2}\right]} \\
d-d \\
{\left[\mathrm{Ni}(\mathrm{OAc})_{2} \cdot 2 \mathrm{H}_{2} \mathrm{O}\right]} \\
d-d\end{array}$ & $\begin{array}{l}191 \\
218 \\
268 \\
344 \\
669 \\
214 \\
397 \mathrm{br}\end{array}$ & $\begin{array}{l}0,598 \\
0,183 \\
0,374 \\
0,948\end{array}$ & $\begin{array}{l}29900 \\
9150 \\
18700 \\
47400\end{array}$ \\
\hline $\begin{array}{l}{\left[\mathrm{Cu}(\mathrm{tta})_{2}\right]} \\
d-d \\
{\left[\mathrm{Cu}(\mathrm{OAc})_{2} \cdot \mathrm{H}_{2} \mathrm{O}\right]} \\
d-d \\
d-d\end{array}$ & $\begin{array}{l}217 \\
279 \\
339 \\
629 \\
212 \\
380 \\
674\end{array}$ & $\begin{array}{l}0,179 \\
0,446 \\
1,211\end{array}$ & $\begin{array}{l}8950 \\
22300 \\
60550\end{array}$ \\
\hline $\begin{array}{l}{\left[\mathrm{Zn}(\mathrm{tta})_{2}\left(\mathrm{H}_{2} \mathrm{O}\right)_{2}\right]} \\
{\left[\mathrm{Zn}(\mathrm{OAc})_{2} \cdot 2 \mathrm{H}_{2} \mathrm{O}\right]}\end{array}$ & $\begin{array}{l}191 \\
233 \\
246 \\
270 \\
337 \\
194\end{array}$ & $\begin{array}{l}0,854 \\
0,234 \\
0,128 \\
0,499 \\
1,794 \\
1.358\end{array}$ & $\begin{array}{l}42700 \\
11700 \\
6400 \\
24950 \\
89700\end{array}$ \\
\hline
\end{tabular}

The electronic spectra of all complexes in acetonitrile are very similar to each other and consist of three bands in the regions of 190 to $350 \mathrm{~nm}$, which clearly shown in one large band for the free H-tta. These absorption bands have assigned to HOMO $\rightarrow$ LUMO transitions due to charge transfer or intra-ligand transitions. In contrast to the H-tta ligand, the generally increasing wavelengths (i.e. lower transition energy gap) are observed due to the lowering energy band gap $\left(E_{\mathrm{HOMO}}-E_{\mathrm{LUMO}}\right)$. The energy gap decreases because the delocalization of $\pi$-electrons along the conjugated backbone. The $\pi$-conjugation makes more occupied levels available at higher energies and this is the reason for the lower of the band gap $\left(E_{\mathrm{HOMO}}-E_{\mathrm{LUMO}}\right)$, which shifts the oxidation potentials of thiophene ring to the lower value. In the same time the reduction of the metal must be higher.

The appearance of a single d-d transition (at $563 \mathrm{~nm}$ ) in the cobalt complex is attributed to the low spin sixcoordinate distorted octahedral [21].

The electronic spectra of all the copper(II) complexes in acetonitril show a broad band centred at $629 \mathrm{~nm}$. This broadband is assigned to four-coordinate square-planar geometry [22]. This $d$ - $d$ transition is in the region of that observed for structurally well-characterized complexes of copper(II) with the square-planar geometry [23]. The other intense bands are due to charge transfer or intra-ligand transitions.

\section{Conclusion}

The metal $\beta$-diketonate complexes showed almost similar electrochemical fashion in acetonitrile. We could conclude from the cyclic voltammetry that the direct reaction of H-tta ligand with metal atom is followed by 310 more negative shifts, reflecting a higher electron density in the metal center of complexes. In addition, the major and minor oxidation potentials related to thiophene entity shifts to the lower potentials which indicate for extending of the $\pi$ systems in complex through $\mathrm{O}-\mathrm{M}-\mathrm{O}$ unit. In addition, the direct reaction of $\mathrm{H}$-tta ligand to the metal atom (atomic overlap in metal-ligand bond) decreases the HOMOLUMO transition (charge transfer of intra-ligand transitions). From the other side, the easier oxidation of thiophene suggests an increase HOMO energy level. This can decrease the charge transfer (MLCT) energy gap. In addition, the more negative potential for the reduction of $\beta$-diketonate moiety suggest an increase in LUMO energy level.

\section{References}

[1] P. A. Vigato, V. Peruzzo, and S. Tamburini, "The evolution of $\beta$-diketone or $\beta$ - diketophenol ligands and related complexes“, Coord. Chem. Rev., 253 (2009) 1099-1201.

[2] O.M. Yaghi, M. O'Keeffe, N.W. Ockwig, H.K. Chae, M. Eddaoudi, and J. Kim, "Reticular Synthesis and the Design of New Materials", Nature, 423 (2003) 705-714. 
[3] S. Kitagawa, R. Kitaura, and S.I. Noro, "Functional Porous Coordination Polymers" Angew Chem, Int. Ed., 43 (2004) 2334-2375.

[4] B. Zhao, X.Y. Chen, P. Cheng, D.Z. Liao, S.P. Yan, and Z.H Jiang, "Coordination Polymers Containing 1D Channels as Selective Luminescent Probes", J. Am. Chem. Soc., 126 (2004) 15394-15395.

[5] Y.-B. Dong, R.C. Layland, N.G. Pschirer, M.D. Smith, U.H.F. Bunz, and H.-C. zur Loye, "New Crystalline Frameworks Formed from 1,2-Bis(4-pyridyl)ethyne and $\mathrm{Co}\left(\mathrm{NO}_{3}\right)_{2}$ : Interpenetrating Molecular Ladders and an Unexpected Molecular Parquet Pattern from T-Shaped Building Blocks", Chem. Mater., 11 (1999)1413-1415.

[6] I. A. Baidina, P. A. Stabnikov, S. A. Gromilov, and I. K. Igumenov, "Crystal structure and thermal investigation of bis-(1-thenoyl-4,4,4-trifluorobutan-1,3-dionato) lead(II)", J. Struct. Chem. 46 (2005) 328-333.

[7] M. Al-Anber, H. Daoud, H. Lang, T. Ruffer, 3Dsupermolecular structure and electronic absorption of uranyl $\beta$-diketone $\left[\mathrm{UO}_{2}(\mathrm{tfa})_{2}(\mathrm{~L})\right]\left(\mathrm{L}=\mathrm{H}_{2} \mathrm{O}, \mathrm{OHCH}_{2} \mathrm{CH}_{3}\right)$ complex. J. Molecular Structure. 997 (2011) 1-6.

[8] For $\left[\mathrm{Cu}(\mathrm{tba})_{2}\right]$ : M. Al-Anber, H. Daoud, T. Ruffer, P. Ecocord , and H. Lang, "Synthesis, Crystal Structure and Spectroscopic Studies of $\left[\mathrm{Cu}(\mathrm{tba})_{2}\right]$ Complex (tba $=$ deprotonated of 3-benzoyl-1.1.1-trifluoro-acetone)", Arabian J. Chem., xxx (2012) xxx, DOI: 10.1016/j.arabjc.2012.04.048. For $\left[\mathrm{Cu}(\mathrm{tta})_{2}\right]$ : M. Al-Anber, P. Ecorchard, T. Ruffer, and H. Lang, J. Saud. Chem. Soc. (2012) Submitted for publication.

[9] M. Al-Anber, P. Ecorchard, T. Rüffer and H. Lang, "Layers of a Cobalt(II) Thenoyl- $\beta$-Diketonato Complex by Supramolecular Recognition.“ Main group Chem., 11 (2012) 205.

[10] A.J. Bard, and L.R. Faulkner, Electrochemical Methods: Fundamentals and Applications, John Wiley and Sons, New York, 2000

[11] R.S. Nicholson, and I. Shain, "Theory of stationary electrode polarography: single scan and cyclic methods applied to reversible, irreversible, and kinetic systems", Anal. Chem., 36 (1964) 706-123.

[12] G. Gritzner and J. Kuta,"Recomendations on reporting electrod potentials in non-aqoueous solvents", Pure \& Appi. Chain., 56:4 (1984) 461-466.

[13] B. Nessakh, G. Horowitz, F. Garnier, F. Deloffre, P. Srivastava and A. Yassar, "Cyclic voltammetry and differential cyclic voltabsorptometry of soluble oligothiophenes: evidence for a four-fold charged $\pi$-dimer in duodecithiophene", J. Electroanalytical Chem., 399 (1995) 97-103.
[14] M. Al-Anber, "Overview of cyclicvoltammetric study and conductivity of some fluorinated $\beta$-diketone containing Thenoyl unit." J. Saudi Chem. Soc., 10 (2006) 347-360.

[15] L.Tatar Yıldırım, K. C. Emregül, R. Kurtaran,O. Atakol, Structure and Electrochemical Behaviour of Bis[N-(4methylphenyl)salicylaldimine]copper(II), Cryst. Res. Technol., 2002, 37 (2002) 1344-1351.

[16] Z. A. Al-Anber, M. A. Al-Anber, S. Al-Tawail, "Electrochemical Behavior of Thienyl-Fluorinated $\beta$-Diketone Substrates and their Conductivity in Solution." Asian J. Chem., 20 (2008) 1675-1690.

[17] R. R. Contreras, T. Suárez, M. Reyes, F. Bellandi, P. Cancines, J. Moreno, M. Shahgholi, A. J. Di Bilio, H. B. Gray, and B. Fontal, "Electronic Structures and Reduction Potentials of $\mathrm{Cu}(\mathrm{II})$ Complexes of [N,N amino-1- cyclopentenecarbothioate)] (Alkyl=Ethyl, Propyl, and Butyl)", Struct. \& Bond., 106 (2004) 71-79.

[18] A. Kilic, E. Tas, and I. Yilmaz, " Synthesis, spectroscopic and redox properties of the mononuclearNiII, NiII(BPh2)2 containing (B-C) bond and trinuclear CuII-NiII-CuIItypemetal complexes of $\mathrm{N}, \mathrm{N}^{\prime}-(4$-amino-1-benzyl piperidine)glyoxime”, J. Chem. Sci., 121, (2009) 43-56.

[19] G. Nemtoi, H. Chiriac, O. Dragos, M.-O. Apostu, and D. Lutic, "The Voltammetric Characterization of the Electrodeposition of Cobalt, Nickel and Iron on Gold Disk Electrode", Acta Chemica IASI, 17 (2009)151- 168.

[20] M. Palacio, A. Juillard, P. Leduc, P. Battioni, D. Mansuy, "One-pot dodecanitration of $\mathrm{Zn}(\mathrm{II})$ and Ni(II)meso-tetrakis(2,6-dichlorophenyl) porphyrin, and extreme redox properties of the obtained complexes", J Organomet. Chem., 643 (2002), 522-524

[21] S. Belaid, A. Landreau, O. Benali-Baitich, M.A. Khan, and G. Bouet, "Synthesis, characterisation and antifungal activity of a series of Cobalt(II) and Nickel(II) complexes with ligands derived from reduced $\mathrm{N}$, N0-0Phenylenebis(Salicylideneimine).”, Trans. Met. Chem., 33 (2008) 511

[22] X.R. Bu, C.R. Jackson, D. Van Derveer, X.Z. You, Q.J. Meng, R.X. Wang, "New copper(II) complexes incorporating unsymmetrical tetradentate ligands with cis-N2O2 chrmophores-synthesis, molecular-structure, substitut effect and thermal-stability“, Polyhedron 16:17 (1997) 2991-3001.

[23] D. M. Boghaei and M. Lashanizadegan, "Template syntheis, characterization of high unsymmetrical tetradentate schiff base complexes of nickel(II) and copper(II)", J. Sci. I.R. Iran 11 (2000) 301-304. 